\title{
A PRELIMINARY ANALYSIS OF BIDAYUH JAGOI PATUN
}

\author{
Mary Fatimah Subet ${ }^{1}$ \\ Shanthi Nadarajan ${ }^{2}$ \\ Dayang Sariah Abang Suhai ${ }^{3}$ \\ Centre for Language Studies, Universiti Malaysia Sarawak \\ ${ }^{1}$ sufatimah@cls.unimas.my \\ 2nshanthi@cls.unimas.my \\ 3asdsariah@cls.unimas.my
}

\begin{abstract}
Bidayuh Pantun or Patun remains a under researched topic in Borneo studies and language research due to the difficulties associated with obtaining critical, poetic information in oral culture, language variations and societal mobility. Existing data from anthologies however provide little detail about the instrinsic and extrinsic features ascribed to the poem by the people who produce and use them. This paper attempts to explore patun from the Jagoi community. In this study, the structural aspects, themes and moral values of 47 patun from the Jagoi community were analysed. The initial explanations suggested by the poet were further analysed to determine the various structural features to place it alongside existing mainstream lyric poetry. The analysis of the intrinsic features showed that good rhythmic patun has four to six words per line and eight to 12 syllables per line, and the final syllables of each line has assonance and consonance patterns of $a-a-a-a$ and $a-b-a-b$. The themes of the patun include love, advice, forgiveness, beliefs, hopelessness and happiness, and the moral values take the form of subtle advice and admonishments. The Bidayuh patun is indeed a projection of knowledge, experiences, beliefs, values, and emotions of the community.
\end{abstract}

Keywords: Patun, unique, mutual discourse, structural aspects, rhythmic verses

\section{Introduction}

The Bidayuh community in Sarawak is the second largest indigenous group in Sarawak, after the Iban, with a population of 198,473 making up $8 \%$ of the Sarawak population of 2,471,140 (Department of Statistics Malaysia, Sarawak, 2012). The Bidayuh live in predominantly Bidayuh areas such as Siburan, Serian, Padawan, Bau, Lundu and Samarahan. The Bidayuh groups in Bau believe that their ancestors originated from the top of Bung Bratak (Bratak Hill) before they dispersed into different areas and set up distinct linguistic groups as a result of attacks by warring communities. Today, a great majority of Bidayuh in Bau are Christians (Roman 
Catholics in particular) and Singai continues to be used as a language of the church. This is mainly because Singai was one of the first Bidayuh groups that converted from animistic traditions to Christianity following the arrival of Christian missionaries during the British colonial era.

The Bidayuh are made up of several distinct linguistic groups as Bukar Sadong, Biatah, Singai and Jagoi. Jagoi, for instance, is the largest linguistic group in Bau which is a region located approximately $70 \mathrm{~km}$ west of Kuching, the capital city of Sarawak. The language used by this group, which is also called Jagoi, is not only used as a medium of daily interaction among its members, but also spoken by other Bidayuh linguistic groups living in the area as such as Serembuk and Singai. According to Chua (2009), within these dialects Jagoi exists as the dialect with the most speakers, (approximately 7,500) but the speakers can amount to more than 30,400 when the other groups, Serambu, Bratak and Singai, are taken into consideration. While a number of dialects are spoken by different dialectal groups in the region, Jagoi remains distinct from the other dialects due to its phonology. This has been attested by Rensch, Rensch, Joeb, and Ridu (2006) where despite all Bidayuh dialects having only liquid tap/flap [r] when syllable initial and a voiced apical trill [r] when word final, the Jagoi dialects would assume it to have a lateral quality, with speakers thinking of it as / $/$ to mention a case (p. 39). Incidentally, all dialects in the region have lexical and syntactic differences with some language being more pronounced than others depending on the context. Although mutual intelligibility may not be high among these groups, the Bidayuh community share some common literature and language works.

In terms of common literature, Patun is a traditional poetic form that remains an integral part of Bidayuh community in Sarawak. Transmitted across generations as is the case for many oral traditions, the Bidayuh patun is viewed by the community as beautiful rhythmic verse that not only encapsulates, but serves as a source of shared experiences, values, and beliefs that needs to be maintained. Collectively owned by Bidayuh community, patun is considered very much alive, often learned by heart and recited from time to time in rituals and official gatherings. As an important source of culture, patun helps unite members of the Bidayuh community especially when recited collectively and individual during special events, gatherings and festivities. Patun is mainly recited by those who have high status within the community such as tukang gawai or pembaca mantra (ritual masters) during the annual harvest festival celebration. The recitation is usually accompanied by the beating of traditional drums or bergendang, a practice which is not uncommon among the Sarawak Malays as well.

Compared to Malay pantun, Bidayuh patun remains unique due to its distinctive imagery and cultural features. For instance, while both poetic forms share common features such as number of verses (e.g., mostly four-line verses), the unique socio-cultural elements, visual imageries and language style used in Bidayuh patun help create an imagery depicting an inclusive community, landscape features and communal engagement as members partake in an exchange of ideas, beliefs, and experiences during patun recital. These unique features need to be explored to provide a better understanding of patun and Bidayuh community and highlight their cultural artefact over time. 
Taking these various features into consideration, the emphasis of this paper is restricted to the four-line patun of the Jagoi Bidayuh community. The analysis of the intrinsic aspects of the Bidayuh patun focuses on the structural features such as the language style, rhyme, imagery, tone, feeling, message, attitude while the analysis of the extrinsic aspects focuses on the history and socio-cultural elements that help shape the patun, particularly the themes and moral values.

\section{Methodology}

This is an interpretive study in that the researchers did not in any way participate in the actual patun recitation activities. From collection of 83 patun collected from the four Bidayuh linguistic groups (Bukar Sadong, Bidatah, Jagoi and Singai), 47 patun identified as belonging to the Bidayuh Jagoi community were selected for analysis. The patun were recited by three elders from the community, namely, Ji'iam anak Daek, Ahiem Anak Majin, and Siah anak Daek. They were then invited to explain the verses. The analysis of the intrinsic elements is a follow up from the event and it focuses on structural features such as the stanza, lines, and words counts, syllable, and rhymes as outlined by Hashim Awang (1984). The extrinsic features of the patun will be explained alongside based on what has been explicated from the discussions with the elders. The role bergendang plays in shaping the intrinstic elements of patun is not included in the scope of the study.

\section{Analysis and Discussion}

According to literary critics, for any verse to be considered as a pantun, they must first satisfy a number of intrinsic and extrinsic features.

\section{Intrinsic features of Bidayuh Jagoi patun}

For starters, the last word of the first line must rhyme with the last word of the third line, while the last word of the second line must rhyme with the last word of the fourth line to give it a rhyming pattern (e.g., $a-b-a-b)$. Furthermore, each line may consist of eight or more syllables (e.g., 9, 10, and 12). The first two lines serve as a lead-in for the message that can be found in the last two lines. The lead-in, also known as the "rhymer", serves as an indicator of the message that appears in the concluding lines of a pantun.

In terms of lines in a stanza, Bidayuh patun of the Jagoi community mostly appear as four-line stanzas as shown in the example in Table 1. 
Table 1

Joget Sowa Bauh by Ji'iam anak Daek, 61 years old

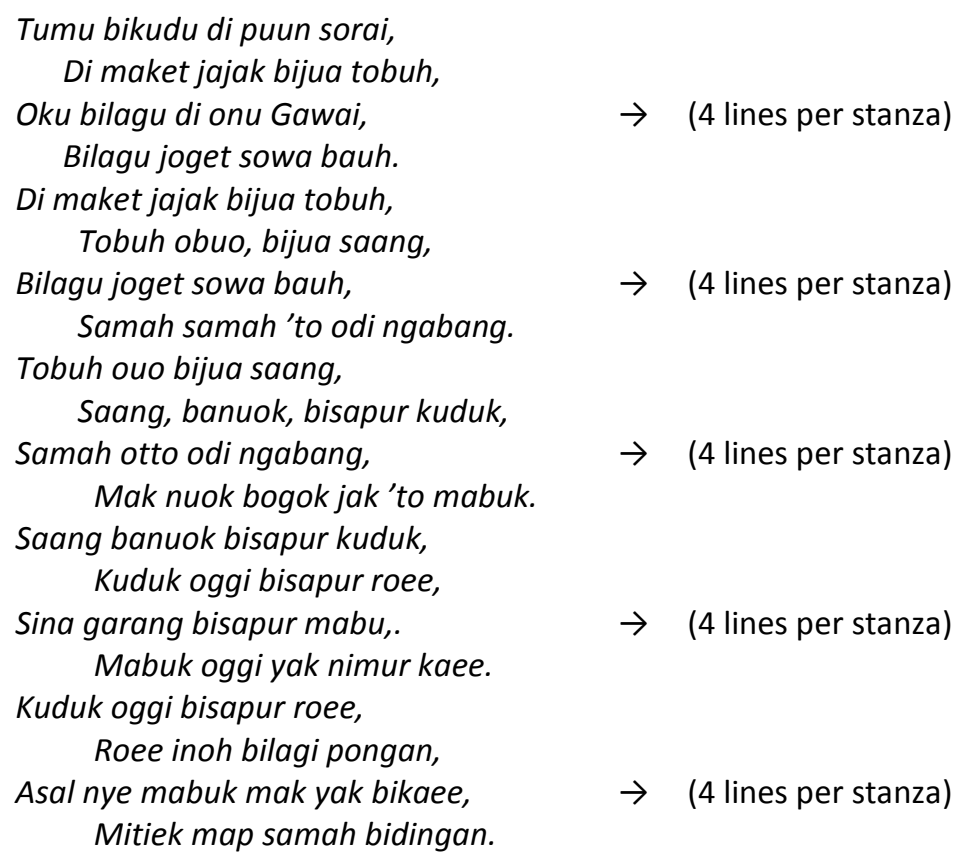

All five stanzas in the song are composed in lines of four per stanza. Most of the patun of the Bidayuh's Jagoi community are composed in this manner. The total number of lines in a stanza of patun - be it two, four, six or eight - create its own uniqueness. The four-line stanzas as shown in the above example are similar to those of the Malay pantun.

In addition to the number of lines, Jagoi patun is also created by carefully taking into account the number of words per line in a stanza. A good patun usually comprises four to six words per line. In terms of prosody, four to six words per line will make a good rhythmic patun and will sound orderly when recited. Examples of four to six words in a line are shown in Table 2.

Table 2

Classical Bidayuh Patun (Part 1) by Ahiem Anak Majin, 66 years old

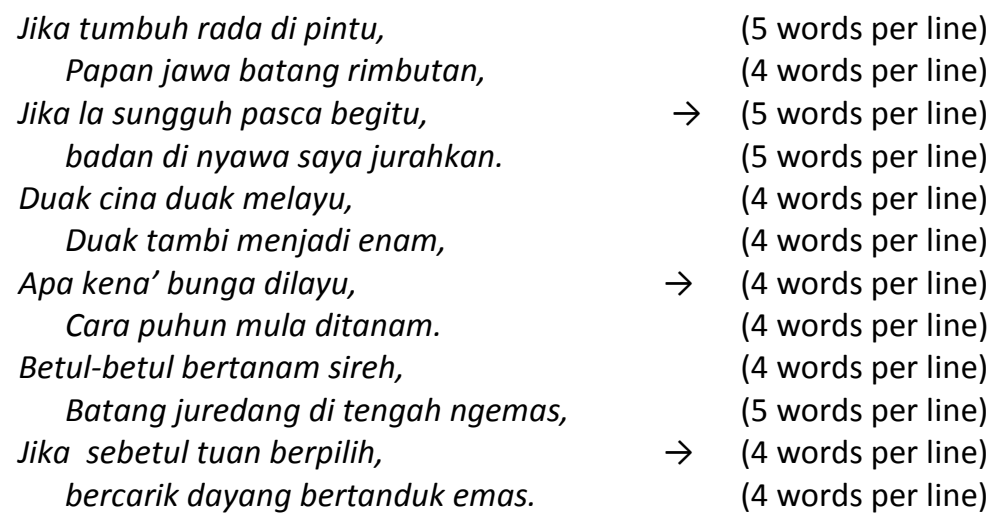


Batang juredang di tengah ngemas, Burung tekukur terebang tinggi,

Bercarik dayang bertanduk emas, bencarik ekor yang bershama tinggi.

Mudah-mudahan limau berbuah, Sigeklah batang lirimau manis,

Mudah-mudahan badan bertuah, Mendapat bunga sekuntum manis.

Rumah bugok pintu sembilan, Naik terubuh tiada' rubuh,

Bagai pugguk merindu rimbulan, Menanti jatuh tiada jatuh.

Naik terubuh tiada rubuh, Tanamlah cabik ngenak berdaun,

Nanti jatuh tiada berjatuh, Biarku nanti seribu taun.

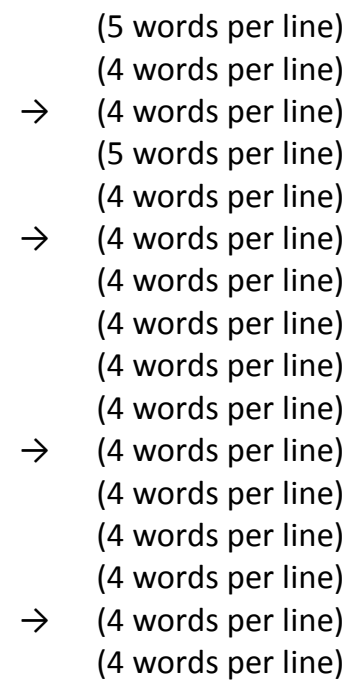

( 5 words per line)

(4 words per line)

$\rightarrow \quad$ (4 words per line)

(5 words per line)

(4 words per line)

$\rightarrow \quad$ (4 words per line)

(4 words per line)

(4 words per line)

(4 words per line)

(4 words per line)

$\rightarrow \quad$ (4 words per line)

(4 words per line)

(4 words per line)

(4 words per line)

$\rightarrow \quad$ (4 words per line)

(4 words per line)

A number of four to six words per line in the above examples make a patun rhythmic when recited, and this leads to eight to twelve syllables per line in a stanza of quatrain as shown in Table 3. When recited, the patun sounds pleasing to the ear.

Table 3

Classical Bidayuh Patun (Part 2) by Ahiem Anak Majin, 66 years old

Ro/mah/go/dang/ber/din/ding/ba/ta/, Te/pat/ting/gal/ ra/ja/ba/ha/ri/,

$\mathrm{Se} / \mathrm{re} / \mathrm{mat} / \mathrm{ting} / \mathrm{gal} / \mathrm{pe} / \mathrm{nyu} / \mathrm{dah} / \mathrm{lah} / \mathrm{ka} / \mathrm{ta} /$, U/mur/ pan/jang/ be/jum/pa/la/gi./

Ma/nih/ be/na /bu/ah/ram/bu/tan/ $\mathrm{Bu} / \mathrm{ah} / \mathrm{pa} / \mathrm{di} / \mathrm{di} / \mathrm{lan} / \mathrm{tai} / \mathrm{ko} / \mathrm{ta} /$

Ma/nih/be/na/pa/ras/mu/tu/an/ $\mathrm{Te} / \mathrm{me} / \mathrm{sih} / \mathrm{ko} / \mathrm{pi} / \mathrm{ta} / \mathrm{ru} / \mathrm{h}$ di/gu/la

Li/mak/la/li/mak/ja/ri/di/ta/ngan/, Du/ak/ta/ngan/ja/di/se/pu/luh./,

Su/dah/me/na/nam/ bu/ah/je/rin/gan/ $\mathrm{Pa} / \mathrm{ri} / \mathrm{ak} / \mathrm{mu} / \mathrm{da} / \mathrm{be} / \mathrm{rik} / \mathrm{di} / \mathrm{tum} / \mathrm{buh} /$

Du/ak/la/du/ak/ta/ngan/ja/di /se/pu/luh/, Ta/nam/lah/ bu/luh /di/da/lam/pa/dang/

Pa/ri/ak/mu/da /be/rik/di/tu/muh/ $\mathrm{Ji} / \mathrm{ka} / \mathrm{lau} / \mathrm{tu} / \mathrm{muh} / \mathrm{ja} / \mathrm{ngan} / \mathrm{di} / \mathrm{bu} / \mathrm{ang} /$

Bu/ang/lah/ba/ju/ ka/re/na/ta/peh/ Ta/pis/laa/di/a/ma/ngan/tas/ku/lit/

Bu/ang/lah /ma/lu/ ke/ra/na/ka/seh/ $\mathrm{Ji} / \mathrm{ka} / \mathrm{lau} / \mathrm{ka} / \mathrm{seh} / \mathrm{me} /$ nyan/di / ba/it/

En/cik/a/wan/a/nak/pang/hu/lu/ Du/duk/ber/ma/in/i/kan/be/na/ga/

$\mathrm{Ji} /$ kal/au /tu/an/ ma/ti/nya/da/hu/lu Tung/gu/sa/ya / pin/tu /syur/ga
(9 syllables per line)

(9 syllables per line)

$\rightarrow \quad$ (11 syllables per line)

(9 syllables per line)

(9 syllables per line)

$\rightarrow \quad$ (9 syllables per line)

(9 syllables per line)

(10 syllables per line)

(10 syllables per line)

$\rightarrow \quad$ (9 syllables per line)

(10 syllables per line)

(10 syllables per line)

(12 syllables per line)

$\rightarrow \quad$ (10 syllables per line)

(10 syllables per line)

(10 syllables per line)

(10 syllables per line)

$\rightarrow \quad$ (10 syllables per line)

(10 syllables per line)

(10 syllables per line)

(9 syllables per line)

$\rightarrow \quad$ (10 syllables per line)

(11 syllables per line)

(8 syllables per line) 
The next intrinsic feature of patun is the final syllable of each line. Assonance and consonance play a vital role through the existence of similar vowel sounds at line endings such as $a-a-a-a$, or $a-b-a-b$ that provide a heightened tempo or a signal to the context and content of the recital. This is similar to the rhythmic alliteration such as $a-b-c-a-b-c$ in a sextet stanza and $a-b-c-d a-b-c-d$ in an octave stanza. Table 4 shows more examples of patun that adhere to the rules of this orderly rhyme and metre.

Table 4

Bikalan Stiang by Ji'iam anak Daek, 61 years old

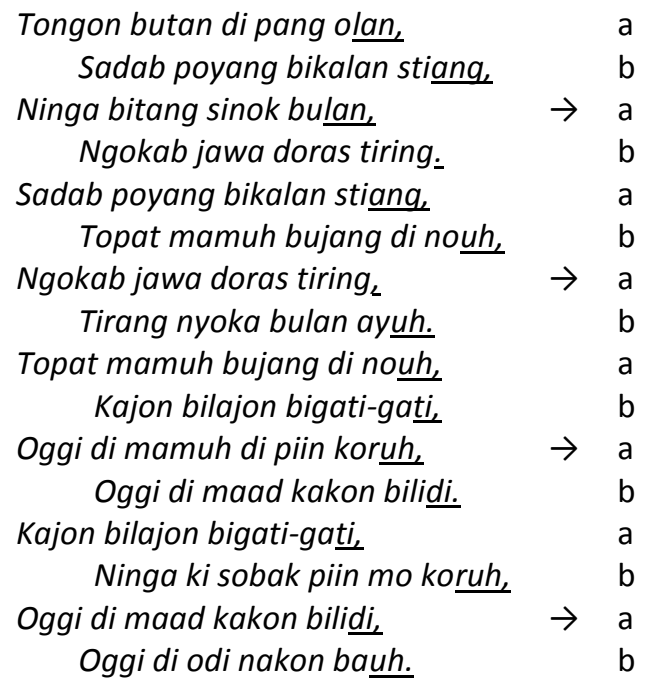

There is a rhythmic assonance pattern of $a-a-a-a$ as shown in Table 5.

Table 5

Patun Patiek by Ji'iam Anak Daek, 61 years old

Bojuh bauh sluar bauh, a

Kan eh pakai rasu yak towoh, a

Sudik eh patuh, sikiek eh paguh, $\rightarrow$ a

Mun baai di piliek duwoh. $\quad$ a

A good patun usually binds itself to the intrinsic features and these help maintain its character and uniqueness. The features must be followed closely by the creators of these patun to retain their significance.

\section{Extrinsic features of Bidayuh Jagoi patun}

The analysis of the extrinsic features of the 47 Jagoi patun revealed the themes and moral values play an important role in maintaining the identity of the Bidayuh patun. Appendix 1 shows examples of patun with good and appropriate choice of theme, 
inculcation of personal beliefs and moral values, portrayal of societal values, advice and subtle sarcasm to name a few.

The choice of themes which border on love, advice, transmitting beliefs, expressing emotions and so forth were chosen based on one's experiences. Besides these themes, thought-provoking patun are also created by including lines that contain moral values which can be in the form of subtle advice or admonishment. Moral values such as honesty, sincerity, patience, tolerance, love, helping one another, kindness, thankfulness, pride and joy, high spirits of motivation and perseverance are also popular. An interesting feature of the recital is that the poets generally end their patun seeking readers' forgiveness. Patun is uttered merely to deliver advice, without any intention to offend any party. It serves as a form of entertainment rather than revenge, as follows:

Pantun Nasihat/Gurauan

(by Siah anak Daek, 51 years old)

Dorod Stapok jadin kuali Nyaa kroja nun batuh karang

Bitapok bidenam di soon skali

Oku suka biterus terang.

Guru-guru to ninga katun Ninga katun di kasa tibi

Idoh dik oku ponai bipatun Patun oku simadi madi.

Batu Kawah sungi bisokap

Topat nyaa slalu ngijala

Salah silap ku mitiek map

Oku sikadar manusia biasa.

\section{Pantun Nasihat/Gurauan}

(Translated to Malay)

Gunung Stapok menjadi kuali

Orang kerja ambil batu karang

Berdendam tidak sama sekali

Saya suka berterus terang

Duduk-duduk tengok kartun

Tengok kartun di kaca tv

Bukan saya pandai berpantun

Pantun saya sahaja sahaja

Batu Kawah sungai bercabang

Tempat orang selalu menjala

Salah silap ku minta maaf

Aku sekadar manusia biasa

The underlying aim of many of these patun is raising the listeners' awareness and appreciation of the lines for its merits. The patun creator goes to great lengths to ensure that the listeners take them in good faith and do not leave the premise with negative feelings. This is probably an intrinsic aspect of the culture itself where the speakers take precaution to ensure that they do not unintentionally belittle or ridicule anyone through their callous banter or lyrics. In other words, the patun is meant to entertain, raise awareness about the communities' values and inculcate tolerance and never to hurt or put anyone down.

Fowler $(1965$, p. 217) states that literature is a record of writers attempting to create and put forward ideas of hope, dreams, emotions, thoughts and experience as well as their relationships with society. Literature talks about humans' life in times of crisis and hurt feelings, and teaches about love, hatred, motivation, dignity, hope, sympathy and sacrifice. In this matter, the Jagoi patun is no different. Fowler's statements hold much truth in that pantun or any other kind of creative oral traditional writings are created as written projections of emotions such as happiness or sadness that one can feel. Mohd Amin Arshad (1988) pointed out that 
creative writing exists as a product of creative and imaginative thinking, brought forward via literature. All these are a record of the poet's intention to put forward their ideas of hopes, dreams, ambitions, thoughts, emotions, experiences and so forth in humans' life. Therefore, in this context the Jagoi patun projects all aspects of life. These life aspects are used as teaching and learning tools, especially to create a balance in one's insight, mental judgement, emotions, characters and one's social well-being. Hence, it can be said that the patun and the Jagoi community's insight, mental judgement, emotions, characters and one's social well-being are strong combinations of individual growth and therefore non detachable. In addition, Wilkinson and Winstedt (1957) also stated that:

One of the most important objects of Malay research is to enable those who come in contact with the Malay to comprehend his faculty for ideas and his range of passim. No one would attempt the mental history of England without study of its literature; of the Scot without study of Burns; and no one can estimate the mental scope of the Malay without an understanding of the pantun. (p. 3)

Wilkinson and Winstedt's contention makes much sense in the context of Bidayuh verses. Patun plays a vital role for helping the world understand the mental scope of the Malays. Similarly, the culture, the beliefs, and the welstanchaunng (material culture) of the Bidayuh's community is best understood via patun. Additional and systematic insights into the Bidayuh language and literature will enable the outside world to not only understand the language, culture, beliefs, and welstanchaunng but also the history and development of the Bidayuh's cultural roots and their place in the community.

\section{Conclusion}

To conclude, it must be said that the Jagoi patun is just one of the ways to visualise and identify key elements that provide an insight into a fast diminishing agrarian lifestyle that is being taken over by development in Sarawak. The patun therefore holds much promise and mirrors many other native communities' aspirations, concerns and experiences in the region. Jagoi patun remains important for two important reasons: firstly, it can serve as important resource for documenting social interaction patterns; and secondly, it also helps bring urban Bidayuh closer to one another and to the cultural aspects of their lives. It can also motivate members of the community to engage in mutual discourse, recreate and promote greater inclusivity and respectfulness. Passed on from one generation to the next, the patun remain as a beautiful rhythmic verse that encapsulates the communities' experiences, beliefs, values, emotions, and as a vital source of communal experiences. Therefore, these patun should be seen as tools that help boost interaction, creation, cultural dialogues and communal engagement.

Presently, given the internet and greater awareness about the need to maintain language rights and cultural resources, opportunities to expand the use of patun among its community members can open doors to emerging new social 
spaces, ideas, and language growth. It will also provide increased focus on getting people to have a say in matters that interest them. The society may be changing and cultures melting, but patun gives the Bidayuh an opportunity to share a common point of view and help members understand new concepts. It is a means of paving the way to overcome new walls, meeting new friends, remembering a distant past.

\section{References}

Chua, L. (2009). To know or not to know? Practices of knowledge and ignorance among Bidayuhs in an 'impurely' Christian world. Journal of the Royal Anthropological Institute, 15, 332-348.

Department of Statistics Malaysia, Sarawak. (2012). Monthly statistical bulletin Sarawak: May 2012. Kuching, Malaysia: Department of Statistics Malaysia, Sarawak.

Fowler, M. E. (1965). Teaching language, composition and literature. New York, NY: McGraw-Hill.

Mohd. Amin Arshad. (1988). Satu kajian mengenai permasalahan penggunaan bahan Kesusasteraan Melayu dalam pengajaran bahasa Malaysia di Tingkatan 4. Unpublished master's thesis, Faculty of Educational Studies, Universiti Pertanian Malaysia, Selangor, Malaysia.

Hashim Awang. (1984). Teman pelajar kesusasteraan. Petaling Jaya, Malaysia: Penerbit Fajar Bakti Sdn. Bhd.

Rensch, C. R., Rensch, C. M., Noeb, J., \& Ridu, R. S. (2006). The Bidayuh language: Yesterday, today and tomorrow. Kuching, Malaysia: Dayak Bidayuh National Association.

Wilkinson, R. J., \& Winstedt, R. O. (1957). Pantun Melayu. Singapore: Malay Publishing House.

Acknowledgement: The writers wish to convey their heartfelt appreciations to UNIMAS for the grant-SGS 03 (S77)/812/2011(11), to Mr. Ji'iam anak Daek, Madame Ahiem Anak Majin and Madam Siah anak Daek for their kind contributions of the Bidayuh Jagoi's patun which are discussed and taken as examples in this article, and also to the Bau District Office for providing the information on Bau-Bidayuh Dialects statistics. 


\section{Appendix 1: Themes and moral values in Patun}

\section{Patun}

\section{Joget Sowa Bauh}

(by Ji'iam anak Daek, 61 years old)

Theme: Happiness

Moral value: Visiting each other, don't drink

too much, don't quarrel, seeking forgiveness

Tumu bikudu di puun sorai,

Di maket jajak bijua tobuh,

Oku bilagu di onu Gawai,

Bilagu joget sowa bauh.

Di maket jajak bijua tobuh, Tobuh obuo, bijua saang,

Bilagu joget sowa bauh, Samah samah 'to odi ngabang

Tobuh ouo bijua saang,

Saang, banuok, bisapur kuduk,

Samah otto odi ngabang,

Mak nuok bogok jak 'to mabuk.

Saang banuok bisapur kuduk,

Kuduk oggi bisapur roee,

Sina garang bisapur mabu,. Mabuk oggi yak nimur kaee.

Kuduk oggi bisapur roee, Roee inoh bilagi pongan,

Asal nye mabuk mak yak bikaee, Mitiek map samah bidingan.

\section{Bikalan Stiang}

(by Ji'iam anak Daek: 61 years old)

Theme: Environment

Moral value: Patience

Tongon butan di pang olan, Sadab poyang bikalan stiang,

Ninga bitang sinok bulan, Ngokab jawa doras tirang.

Sadab poyang bikalan stiang, Topat mamuh bujang di nouh, Ngokab jawa doras tiring Tirang nyoka bulan ayuh.

\section{Translation in Malay Joget Tahun Baru}

Tumbuh mengkudu di pohon serai

Di market jaja menjual tebu,

Saya berlagu di hari Gawai,

Berlagu joget tahun baru.

Di market jaja berjual tebu, Tebu habis, berjual cili,

Berlagu joget tahun baru, Sama-sama kita pergi menziarah.

Tebu habis, berjual cili, Cili, ubi kayu bercampur keladi,

Bersama kita pergi menziarah, Jangan minum banyak nanti kita mabuk.

Cili, ubi kayu bercampur keladi, Keladi ada bercampur halia,

Bercakap garang bercampur mabuk, Mabuk akan menimbulkan pergaduhan.

Keladi ada bercampur halia, Halia itu rempah gulai daging,

Sekiranya mabuk janganlah bergaduh, Minta maaf bersama berkawan.

\section{Bikalan Stiang (nama satu tempat untuk} mandi)

Pohon kelapa di tepi jalan, Tepi kepayang bikalan stiang,

Lihat bintang berdekatan bulan,

Pancaran cahaya terangnya kuat.

Tepi kepayang bikalan stiang, Tempat mandi orang bujang dahulukala, Pancaran cahaya terangnya kuat, Terang memancar bulan purnama. 
Topat mamuh bujang di nouh, Kajon bilajon bigati-gati,

Oggi di mamuh di piin koruh, Oggi di maad kakon bilidi.

Kajon bilajon bigati-gati, Ninga ki sobak piin mo koruh, Oggi di maad kakon bilidi, Oggi di odi nakon bauh.

\section{Patun Ngin Ajar}

(by Ji'iam anak Daek: 61 years old)

Theme: Hopelessness

Moral values: Be a person of virtue, Do not commit any wrong or evil deed

Doik tiborak sumuk ginaka, Doik pirassi doik tiborak,

Sukun eh nuok rasun, pak toro ninga, Pak daap di'eh ponai nang mak.

\section{Pantun Nasihat/Gurauan}

(by Siah anak Daek, 51 years old)

Theme: Love

Moral values: Perseverance, patience, honesty

Tiang taas jading tiboyan Jadin topat so nye posan bunga

Dowon mas bibunga intan Akan ku nupas walaupun tung nyaa.

Batu karang di daang donu Di ropot dorod Batu Kawah

Ku pait salam jobong di muu Yak bidapod sapey nyam payah.

Ikien sipat di dowon koyuh Rabuk ki piin bironang ronang

Bukan sitakat nye oda idip bauh Tandanye rindu otinnye nyayang.

\section{Pantun Nasihat/Gurauan}

(by Siah anak Daek, 51 years old)

Theme: Beliefs

Moral values: Seeking forgiveness, praying, advice

\footnotetext{
So Siniawan odi ki Bau

Muun ninga nyaa biloma

Kakat tongan smoong tilinyuk
}

Tempat mandi orang bujang dahulu kala, Tunggu menunggu berganti-ganti, Ada yang mandi di air yang keruh, Ada yang naik menjinjing baldi.

Tunggu menunggu berganti-ganti, Lihat ke hilir air sudah keruh, Ada yang naik menjinjing baldi, Ada yang pergi menjinjing lagi.

\section{Pantun Nasihat}

Tiada guna nenek derhaka,

Tiada belas tiada kasihan,

Cucu minum racun termenung melihat,

Tercegat sahaja tanpa berkata jangan.

\section{Pantun Nasihat/Gurauan}

Tiang jati jadi jambatan,

Menjadi tempat letak bunga,

Daun emas berbunga intan,

Akan ku petik walaupun orang yang punya.

Batu karang di dalam hutan,

Di kaki gunung Batu Kawah,

Ku kirim salam rindu padamu, Ingin bertemu sangatlah susah.

Ikan sepat di daun kayu, Jatuh ke air berenang renang,

Bukan setakat suruh hidup kembali, Tanda rindu hatinya saying.

Pantun Nasihat/Gurauan

Dari Siniawan pergi ke Bau,

Turun melihat orang berlumba, Angkat tangan sepuluh jari, 
Mitiek apun map di Topa.

Ruang kasang biyon di ragak Buak bungul nyikon di boru

Odi smayang bidoa di Topa

Mitiek bidoa oda umur omu.

Bojuh omu sluar kodok

Bojuh motong di kedey teller

Oni di toru dosa nye bogok

Dapod nye ngapun tanon di Topa.

Bila bigawea nye mo nai pogang

Ogi taya gutan tun akat

Sitigal karoke nye ngabai smayang

Watnoh keh gaya nye nyaran adat

\section{Pantun Nasihat/Gurauan}

(by Siah anak Daek, 51 years old)

Theme: Forgiveness

Moral value: Humility

Batu Kawah sungi bisokap Topat nyaa slalu ngijala

Salah silap ku mitiek map

Oku sikadar manusia biasa.

\section{Pantun Nasihat/Gurauan}

(by Siah anak Daek, 51 years old)

Theme: Advice

Moral values: Be humble, not egoistic and arrogant

\section{Pakai kreta odi ki Sabah}

Singah ki hotel topat nye boos

Tanon lawa biar disah

Apalagi nye yak supah kobos.
Minta ampun kepada Tuhan.

Biji kacang tuang ke raga,

Bunga balung ayam simpan di

tempurung,

Pergi sembahyang berdoa kepada Tuhan,

Minta berdoa umur panjang.

Baju panjang seluar pendek,

Baju dipotong di kedai jahit,

Kenapa takut banayak dosa,

Dapat kita minta ampun pada Tuhan.

Bila bergawai kita buat lemang,

Ada tayar digantung atas akat (sejenis tiang),

Gara-gara karaoke sembahyang diabai,

Begitukah kita menjalankan ibadah?

Pantun Nasihat/Gurauan

Batu Kawah sungai bercabang,

Tempat orang selalu menjala,

Salah silap ku minta maaf,

Aku sekadar manusia biasa.

\section{Pantun Nasihat/Gurauan}

Guna kereta pergi ke Sabah

Singgah ke hotel tempat tidur

Berkata sombong biarlah usah

Apalagi nak bersumpah mati 